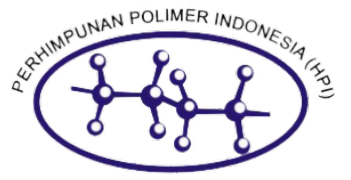

\title{
Studi $\boldsymbol{A} \boldsymbol{b}$ Initio Interaksi Molekul Poliblend Kitosan - Poli Asam Akrilat sebagai Bahan Penghantar Ion
}

\author{
La Ode Ahmad Nur Ramadhanª, La Agusub ${ }^{\mathrm{b}}$, Laode Abdul Kadir \\ Fokus dari penelitian ini adalah untuk melihat interaksi membran poliblend kitosan-poli asam akrilat sebagai bahan \\ penghantar ion dengan metode $A b$ Initio. Optimasi geometri dilakukan dengan metode B3LYP dan basis set 3-21G. Dari \\ hasil optimasi terlihat bahwa interaksi membran poliblend kitosan-poli asam akrilat terbentuk dari ikatan gugus amina \\ kitosan dan gugus karboksilat asam akrilat (10N ---- H21) dengan jarak ikatan 1,47 ̊̊ dan sudut $112,04^{\circ}$. Interaksi \\ membran poliblend kitosan-poli asam akrilat dengan satu molekul air juga dipelajari. Dari hasil studi menunjukkan \\ perubahan energi interaksi antara kitosan-poli asam akrilat dengan satu molekul air adalah 179,759 kJ mol-1. Terdapat \\ tiga ikatan hidrogen yang terbentuk yakni 23H ----- 039, 390 ------ $\mathrm{H} 21$ dan $41 \mathrm{H} \mathrm{------} \mathrm{O32.} \mathrm{Kekuatan} \mathrm{ikatan} \mathrm{hidrogen}$ \\ tersebut berada pada rentang sedang yakni berkisar $1,55-1,72 \AA$.
}

This research focuses on the interaction of the chitosan-poly acrylic acid polyblend membrane as an ion conductor with the $A b$ Initio method. Geometry optimization is done by the B3LYP method and base set 3-21G. From the optimization results, it can be seen that the interaction of the chitosan-poly acrylic acid polyblend membrane is formed from the

Received

10 October 2018

Received in revised form

Accepted

28 December 2018

Published

31 December 2018 chitosan amine group bond and the acrylic acid carboxylic group (10N ---- H21) with a bond distance of $1.47 \AA$ and an angle of $112.04^{\circ}$. The interaction of chitosan-poly acrylic acid acrylic membrane with one water molecule was also studied. The study results showed that the change in the interaction energy between chitosan-poly acrylic acid and one water molecule was $179.759 \mathrm{~kJ} \mathrm{~mol}^{-1}$. There are three hydrogen bonds formed, namely $23 \mathrm{H} \mathrm{-----} \mathrm{039,390} \mathrm{------} \mathrm{H} 21$, and $41 \mathrm{H}$ ----- 032. The strength of the hydrogen bond is in the medium range, which ranges from 1.55-1.72 $\AA$.

DOI: $10.37889 / \mathrm{mpi}$.2018.21.2.1

Kata kunci: $A b$ Initio, kitosan, membran poliblend, poli asam akrilat.

\section{Pendahuluan}

Salah satu komponen penting dalam sel bahan bakar Proton Exchange Membrane Fuel Cell (PEMFC) adalah membran polimer elektrolit. Pada umumnya membran polimer elektrolit yang digunakan secara komersial hingga saat ini adalah Nafion. Harga yang mahal dan tidak ramah lingkungan bila bahan tersebut tidak digunakan lagi menjadi salah satu kelemahan Nafion sehingga diperlukan usaha untuk mendapatkan material lain sebagai pengganti. Salah satu material yang berpotensi adalah kitosan, suatu selulosa yang diisolasi dari limbah cangkang udang, yang dimodifikasi secara kimia dengan poli akrilat, untuk meningkatkan konduktivitas protonnya. ${ }^{1-2}$

Untuk menjelaskan pengaruh modifikasi-modifikasi material penyusun membran serta memastikan interaksi antar molekul penyusun membran, diperlukan penjelasan teoritis tentang interaksi membran poliblend yang berdampak pada nilai konduktivitas proton dari modifikasi tersebut. Penjelasan secara teoritis dapat dilakukan dengan cara pemodelan terhadap molekul penyusun membran dan mensimulasi kondisi-kondisi tertentu yang sesuai dengan lingkungan kimiawinya.

\footnotetext{
a. Jurusan Kimia, Fakultas Matematika dan IImu Pengetahuan Alam, Universitas Halu Oleo, Kendari, Sulawesi Tenggara

b. Jurusan Fisika, Fakultas Matematika dan IImu Pengetahuan Alam, Universitas Halu Oleo, Kendari, Sulawesi Tenggara

+ Corresponding author: laode.ramadhan@uho.ac.id.
}

Proses simulasi komputer telah memberikan sumbangan terhadap banyak persoalan-persoalan yang sifatnya atomistik dalam kimia. Menurut Hutter, ${ }^{3}$ hasil-hasil simulasi komputasi dapat menghasilkan kajian yang dapat dipakai untuk menafsirkan hasilhasil pengukuran dari eksperimen, memprediksi sifat material, dan atau mendesain senyawa-senyawa baru. Untuk mendapatkan hasil-hasil simulasi yang baik, langkah awal yang tepat adalah mengetahui struktur molekul yang sesuai dan mengetahui garis besar proses dinamik pada skala atomik untuk sistem yang dipelajari.

Pada penelitian ini difokuskan pada perhitungan struktur elektronik secara ab initio membran poliblend kitosan-poli akrilat dan optimasi geometri berbagai struktur untuk mengetahui secara mikroskopis, interaksi intermolekul dan antar molekul membran poliblend kitosan-poli akrilat.

\section{Metode Percobaan}

\section{Metode Komputasi}

Simulasi secara teoritik dilakukan untuk model membran dalam keadaan dasar (dry state) serta dalam keadaan tersolvasi satu molekul air. Optimasi geometri dilakukan dengan metode (Becke, three-parameter, Lee-Yang-Parr) B3LYP dengan basis set 3-21G.

\section{Hasil dan Pembahasan}

Pada penelitian ini dilakukan pemodelan membran komposit dengan mengomplekskan kitosan dengan asam poli akrilat untuk 
sistem membran poliblend. Model membran komposit tersebut berfungsi sebagai membran penghantar ion, sehingga diamati interaksi molekul yang terjadi di dalamnya. Model membran komposit berasal dari asumsi fragmentasi pada molekul membran. Fragmentasi dilakukan untuk menyederhanakan model membran, sehingga bagian membran yang terlibat adalah molekul yang diperkirakan berhubungan langsung dengan proton dalam mekanismenya sebagai transpor ion. Interaksi molekul komposit polimer yang mungkin terjadi dalam membran direplika secara minimal karena kemampuan komputer yang digunakan dalam penelitian ini tidak terlalu besar.

Tahapan kerja yang dilakukan pada penelitian ini adalah memodelkan membran sehingga diperoleh asumsi model interaksi molekul kitosan-poli asam akrilat dalam sistem komposit. Selanjutnya dilakukan optimasi geometri molekul dengan menggunakan metode B3LYP dan basis set 3-21G. Hasil optimasi geometri dianalisis menggunakan prinsip "energi sistem mengarah ke energi yang lebih rendah (entalpi/ $\Delta \mathrm{H}$ terendah) untuk mencapai geometri model yang lebih stabil (entropi/ $\Delta S$ terendah)" dari Hukum Fundamental Termodinamika.

Pembuatan model dalam penelitian ini menggunakan struktur molekul standar yang dihasilkan oleh program Avogadro. Struktur molekul standar dari program Avogadro adalah struktur molekul dengan pengaturan otomatis sesuai dengan database standar panjang ikatan, sudut ikatan dan sudut dihedral setiap molekul dengan energi minimum yang tersimpan dalam program Avogadro.

\section{Model Fragmen Kitosan}

Kitosan (KS) merupakan senyawa organik jenis polikation, sehingga sangat cocok sebagai material dasar pembuatan membran kompleks polielektrolit. Dari struktur (KS) dilakukan fragmentasi struktur, sehingga didapatkan model membran yang diperkirakan berinteraksi langsung dengan ion dan gugus fungsi molekul PAA yang dikompositkan pada matriks KS.

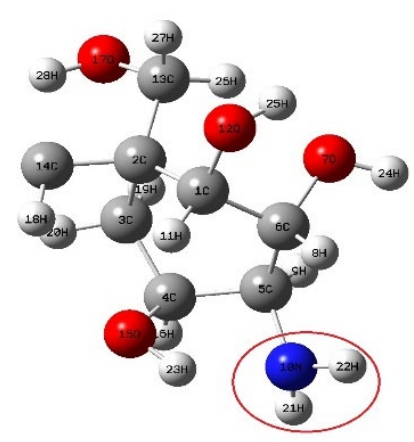

Gambar 1. Sruktur fragmen KS, sketsa 3 dimensi hasil optimasi geometri standar Program Gaussview 5.0, (atom oksigen: bola merah, atom hidrogen: bola putih, atom karbon: bola abu-abu serta atom nitrogen: bola biru tua).

Hasil fragmentasi CS pada Gambar 1 memiliki rumus molekul $\mathrm{C}_{8} \mathrm{H}_{17} \mathrm{NO}_{4}$. Fragmentasi tersebut disesuaikan dengan hasil penelitian Perman. ${ }^{4}$ Dalam penelitiannya, Permana menyebutkan bahwa gugus fungsi amina $\left(-\mathrm{NH}_{2}\right)$ berinteraksi elektrostatik dengan proton karena proton bersifat lebih asam. Gugus amina pada Gambar 1 di- tunjukkan dengan tanda elips merah. Rantai karbon dan gugus hidroksil dari KS $\left(-\mathrm{CH}_{2}-\mathrm{CH}_{2}-\mathrm{O}-\mathrm{H}\right)$ dilibatkan dalam fragmentasi KS untuk mewakili sisi hidrofobik dan hidrofilik membran KS. ${ }^{5}$

\section{Fragmen Interaksi Poli Asam Akrilat - Kitosan}

Poli-asam akrilat (PAA) adalah polimer sintetik yang memiliki berat molekul tinggi dari asam akrilat. Asam poliakrilat adalah polielektrolit anionik lemah, yang tingkat ionisasinya tergantung pada $\mathrm{pH}$ larutan. Dalam bentuk non-ionisasi pada $\mathrm{pH}$ rendah, PAA dapat berhubungan dengan berbagai polimer non-ionik (seperti polietilena oksida, poli-N-vinil pirolidon, poliakrilamida dan beberapa eter selulosa) dan membentuk kompleks interpolimer ikatan-hidrogen.

Fragmen PAA memiliki rumus molekul $\mathrm{C}_{3} \mathrm{H}_{6} \mathrm{O}_{2}$. Pemilihan fragmentasi PAA tersebut dilakukan karena polikation dari matriks $\mathrm{KS}$ memerlukan polianion dari struktur PAA untuk berinteraksi elektrostatik. Penelitian Nurkeeva ${ }^{6}$ menyebutkan bahwa Dalam larutan berair, PAA juga dapat membentuk polikompleks dengan polimer yang bermuatan berlawanan misalnya, kitosan.

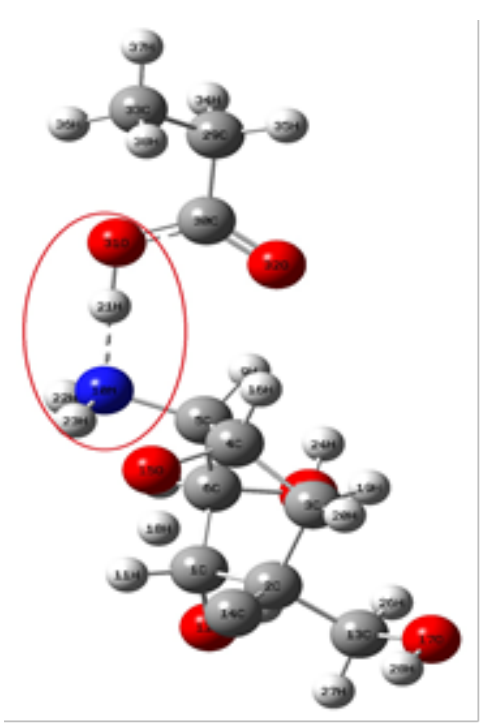

Gambar 2. Sruktur Interaksi KS-PAA, sketsa 3 dimensi hasil optimasi geometri standar Program Gaussview 5.0, (atom oksigen: bola merah, atom hidrogen: bola putih, atom karbon: bola abu-abu serta atom nitrogen: bola biru tua).

Dari Gambar 2 terlihat bahwa interaksi membran poliblend kitosan-poli asam akrilat terbentuk dari ikatan gugus amina kitosan dan gugus karboksilat asam akrilat (10N ------ H21) dengan jarak ikatan $1,47 \AA$ dan sudut $112,04^{\circ}$ seperti yang ditunjukan oleh elips berwarna merah.

Interaksi membran poliblend kitosan-poli asam akrilat dengan satu molekul air juga dipelajari dan hasilnya dapat dilihat pada Gambar 3. Dari hasil studi menunjukkan perubahan energi interaksi antara kitosan-poli asam akrilat dengan satu molekul air adalah $179,759 \mathrm{~kJ} \mathrm{~mol}^{-1}$. Terdapat tiga ikatan hidrogen yang terbentuk yakni $23 \mathrm{H}$----- O39, 390 ----- $\mathrm{H} 21$ dan $41 \mathrm{H}$----- O32. Kekuatan ikatan hidrogen tersebut berada pada rentang sedang yakni berkisar 1,55$1,72 \AA$. 


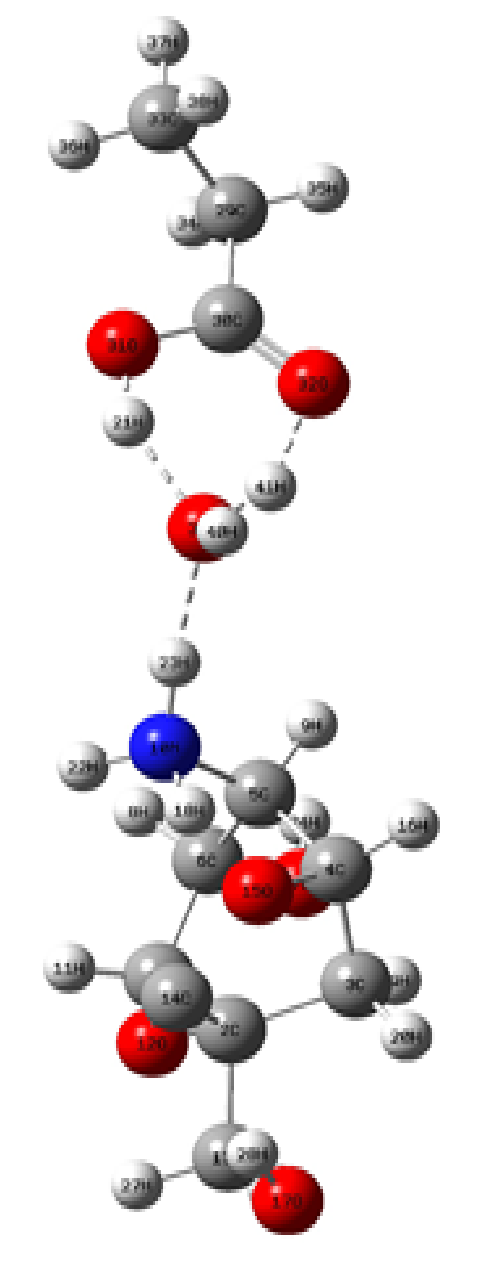

Gambar 3. Sruktur Interaksi KS-PAA-H2O, sketsa 3 dimensi hasil optimasi geometri standar Program Gaussview 5.0, (atom oksigen: bola merah, atom hidrogen: bola putih, atom karbon: bola abu-abu serta atom nitrogen: bola biru tua).

\section{Kesimpulan}

Perubahan energi interaksi antara kitosan-poli asam akrilat dengan satu molekul air adalah $179,759 \mathrm{~kJ} \mathrm{~mol}^{-1}$. Terdapat tiga ikatan hidrogen yang terbentuk yakni $23 \mathrm{H}$----- 039,390

- H21 dan 41H ------- O32. Kekuatan ikatan hidrogen tersebut berada pada rentang sedang yakni berkisar 1,55-1,72 A.

\section{Ucapan Terima Kasih}

Ucapan terima kasih kepada Direktorat Riset dan Pengabdian Masyarakat Direktorat Jenderal Penguatan Riset dan Pengembangan Kementerian Riset, Teknologi dan Pendidikan Tinggi atas Biaya Penelitian PDUPT dengan Kontrak Penelitian Nomor: 056/SP2H/LT/DPRM/2018.

\section{Referensi}

1 B. Smitha, S. Sridhar dan A.A. Khan, Polyelectrolyte complexes of chitosan and poly(acrylicacid) as proton exchange membranes for fuel cells, Macromolecules, 2004, 37(6), 2239.

2 L.O. Ahmad, D. Permana, Wahab, S.H. Sabarwati., L.O.A.N. Ramadhan dan U. Rianse, Improved chitosan production fromtiger shrimp shell waste (Peneausmonodon) by multistage deacetylation method and effect of bleaching, Advances in Environmental and Geological Science and Engineering, 2015, 373-378.

3 J. Hutter, I. Marcella, S. Florian dan J. VandeVondele, CP2K: Atomistic Simulations of Condensed Matter Systems. WIREs Computational Molecular Science, 2013, 00, 1-11.

4 D. Permana, Sintesis dan Karakterisasi Membran Komposit Kompleks Kitosan-Asam Fosfotungsten/Monmorilonit Termodifikasi Silan untuk Aplikasi DMFC, Tesis Magister, Institut Teknologi Sepuluh Nopember, Surabaya, 2015.

5 B.P. Tripathi dan V.K. Shahi, Organic-Inorganic Nanocomposite Polymer Electrolyte Membranes for Fuel Cell Applications, Progress in Polymer Science, 2011, 36, 945-979.

6 Z.S. Nurkeeva, V.V. Khutoryanskiy, G.A. Mun, M.V. Sherbakova, A.T. Ivaschenko, N.A. Aitkhozhina, Polycomplexes of poly(acrylic acid) with streptomycin sulfate and their antibacterial activity, European Journal of Pharmaceutics and Biopharmaceutics, 2004, 57(2), 245-9. 